\title{
US scraps plan to license foreign scientists
}

Scientists in the United States have won a reprieve from a proposed security regulation that would have restricted some foreign researchers' access to laboratories.

On 31 May, the US Department of Commerce announced that it was withdrawing a proposed rule change that would have required scientists and students from "countries of concern $n^{n}$ - including Pakistan, India, Russia and China - to be licensed before using certain pieces of laboratory equipment. The decision, which surprised many, was hailed as a victory by science advocates in Washington DC. They say that the department responded responsibly to hundreds of complaints from researchers.

The rule change was first suggested in 2004 by the department's independent inspectorgeneral, as a modification to the existing 'deemed export regulations' on the export of sensitive technologies (see Nature 431, 615; 2004). The changes would have required some

foreign researchers in the United States to obtain licences to use many pieces of equipment listed as 'controlled', because the devices could be used to strengthen a nation's military capabilities. An unclassified version of the list includes everything from chemical lasers to bacteria.

Science advocates warned the proposal would create a mountain of paperwork and restrict access to laboratories. "It would

"We don't want to create regulations that make the research enterprise less productive."

\section{have changed the whole open-}

campus research environment," says Robert Hardy of the Council on Government Relations, a Washington-based association for research universities.

In a four-page notice in the Federal Register, the official noticeboard of the US government, the department said that an existing exemption for foreign scientists would continue for now. The decision was made partly in response to complaints from universities, industry and even some government labs, according to David McCormick, undersecretary of commerce for industry and security. ${ }^{\alpha}$ We don't want to create regulations that make the research enterprise less productive," he says.

McCormick says that the department is forming a 12 person committee, which he hopes will include experts in academia, industry and security, to examine the issue of laboratory security. The group, he says, will have a mandate to examine "fundamental issues to do with deemed export policy".

Tobin Smith, senior federal-relations officer at the Association of American Universities, says that he feels the group will be able to come to sensible conclusions about security issues. "I'm pretty optimistic," he says.

Geoff Brumfiel 